streets and avenues it is difficult to identify the number of the house. The illumination of these numbers would often be a great boon. In the August number of Helios - the German export journal for the electric industry - it is stated that in many newly built suburbs 'number lamps' have been installed over the front doors or in other convenient spots. Several of the older streets also are being equipped with these lamps. Electricity supply companies are encouraging their use by giving the consumer energy for illuminating the lamps at a specially low rate. The number lamps illustrated in the journal are prismatic in shape, three of the edges being vertical and the top and base being horizontal. Expensive shades in opal glass are sometimes used, but owing to the risk of breakage, most people use a cheaper form. Simple panes of glass are put in a cast iron frame. They can be easily removed for cleaning and in the event of an accident the pane can be easily replaced. The transparent number panes are placed in a black frame and the triangular base of the lamp is provided with an opal glass pane which lights up the entrance to the house.

\section{Physics Research at Harvard}

Contributions from the Physical Laboratories of Harvard University, vol. 22, is a collection of separate copies of 29 papers which have been issued by the Laboratory during the years 1932-33, bound together and provided with a table of contents. It extends to about five hundred pages, but the pagination of the original memoirs is retained. More than half of the volume is occupied by papers written by Prof. P. W. Bridgman or by workers in his laboratory. They add considerably to our knowledge of the properties of substances under great pressures. A paper by Prof. Bridgman puts forward serious criticisms of some of the methods of proof used in the current theory of groups (mengenlehre). Several of the remaining papers issue from the laboratory of Prof. W. Duane, and deal with investigations of atomic and molecular properties, while others dealing with spectroscopic investigations originate in Prof. T. Lyman's laboratory. Two others deal with vapour pressures and entropy, one with the magnetic properties of certain iron alloys, and another with the large changes of ionisation of the atmosphere which are produced by solar eclipses. Readers of these contributions will be struck by the importance of the work which is being done by 'National Research Fellows'.

\section{The Fish and the Ring}

ThE city of Glasgow bears in its coat of arms a fish with a ring in its mouth, and the incident so commemorated involved a lady's honour in the days of St. Kentigeon. But since rubber rings were invented, the association between fish and ring has become a matter of solid fact. In the Australian Museum Magazine of April, G. P. Whitley has collected accounts of curious cases where fishes have become involved in rings, and the examples range from garfish and mackerel with rubber rings sur- rounding and even partly embedded in their bodies, to a shark, captured at Havana, Cuba (recorded by Dr. Gudger), and adorned by a motor-car tyre which encircled its body and was prevented from slipping over the tail by the dorsal fin and from slipping over the head by the pectorals.

\section{Land Speed Record}

Sir Malcolm Campbell made a new world landspeed record on September 3 by driving his Bluebird car on the Bonneville salt flats in Utah at a mean average speed of $301 \cdot 337$ miles per hour. In the first run, he was stated to have covered the measured mile in $11 \cdot 83 \mathrm{sec}$, which works out at 304.311 m.p.h. The second run was stated to have been covered in $12 \cdot 18$ sec., giving a speed of 295.566 m.p.h. His average speed was therefore given as $299 \cdot 875$ m.p.h. Later it was announced that there had been a mis. calculation of the time, and the average speed was corrected to $301 \cdot 337$ m.p.h.

\section{Announcements}

THE autumn meeting of the Institute of Metals will be held at Newcastle-upon-Tyne on September 9-12. The proceedings will begin in the evening with the delivery by Dr. H. W. Brownsdon of the fourteenth annual Autumn Lecture on "Metal Melting: its Effect on Quality". Following the lecture, a general discussion will take place on several different phases of the lecturer's subject. No tickets are required for admission to the lecture, which will be given in the King's Hall, Armstrong College, at 7.15. Visitors are admitted to the business sessions, beginning each morning at 10 a.m., on signing the visitor's book in the New Mining Lecture Theatre, Armstrong College.

A volume of collected researches published from the Wards and Laboratories of the London Hospital during 1934 has been issued (London: H. K. Lewis and Co., Ltd. $7 s .6 d$. net). The papers included extend over a wide range of subjects, and mostly embody original observations of importance for the diagnosis, prognosis and treatment of disease.

Applications are invited for the following appointments, on or before the dates mentioned:

An assistant (Grade II) and a junior assistant in radiological research, a junior assistant and two assistants (Grade II) in ballistics research, and an assistant (Grade I), an assistant (Grade II) and a junior assistant in explosives research, in the Research Department, Woolwich-The Chief Superintendent, Research Department, Woolwich, S.E.18 (Sept. 14).

A junior scientific officer in the Admiralty Scientific Pool-The Secretary of the Admiralty (C.E. Branch), Whitehall, S.W.1 (Sept. 21).

An assistant curator of the Museums in Leeds-. The Town Clerk, Room 57, Civic Hall, Leeds, 1 (Oct. 7).

A lecturer in mathematics in the University of Tasmania-The Agent-General for Tasmania, Australia House, Strand, London, W.C.1. 